\title{
Acta
Biochimica
Polonica
}

Vol. 50 No. 1/2003

$169-179$

www.actabp.pl

\section{Poly(ADP-ribose) polymerase in base excision repair: always engaged, but not essential for DNA damage processing ${ }^{\star}$}

\author{
Sarah L. Allinson, Irina I. Dianova and Grigory L. Dianov ${ }^{\bowtie}$ \\ MRC Radiation and Genome Stability Unit, Harwell, Oxfordshire, OX11 ORD, U.K.
}

Received: 08 September, 2002; revised: 29 January, 2003; accepted: 07 February, 2003

Key words: DNA repair, base excision repair, PARP, abasic sites, in vitro repair, cell extracts

Poly(ADP-ribose) polymerase (PARP-1) is an abundant nuclear protein with a high affinity for single- and double-strand DNA breaks. Its binding to strand breaks promotes catalysis of the covalent modification of nuclear proteins with poly(ADP-ribose) synthesised from $\mathrm{NAD}^{+}$. PARP-1-knockout cells are extremely sensitive to alkylating agents, suggesting the involvement of PARP-1 in base excision repair; however, its role remains unclear. We investigated the dependence of base excision repair pathways on PARP-1 and $\mathrm{NAD}^{+}$using whole cell extracts derived from normal and PARP-1 deficient mouse cells and DNA substrates containing abasic sites. In normal extracts the rate of repair was highly dependent on $\mathrm{NAD}^{+}$. We found that in the absence of $\mathrm{NAD}^{+}$repair was slowed down 4-6-fold after incision of the abasic site. We also established that in extracts from PARP-1 deficient mouse cells, repair of both regular and reduced abasic sites was increased with respect to normal extracts and was $\mathrm{NAD}^{+}$-independent, suggesting that in both short- and long-patch BER PARP-1 slows down, rather than stimulates, the repair reaction. Our data support the proposal that PARP-1 does not play a major role in catalysis of DNA damage processing via either base excision repair pathway.

Base excision repair (BER) is the major pathway for repair of many types of DNA damage, including spontaneously arising lesions, such

as uracil and abasic (AP) sites, and the products of base oxidation and alkylation (Lindahl, 1993). The initiating stage of BER is the re-

\footnotetext{
${ }^{\star}$ Presented at the 32nd Annual Meeting of the European Environmental Mutagen Society, September 2002, Warsaw, Poland.

${ }^{{ }^{T}}$ To whom correspondence should be addressed: Radiation and Genome Stability Unit, Medical Research Council, Harwell, Oxfordshire, OX11 0RD, U.K.; tel. (44) 1235841 134; fax (44) 1235841 200; e-mail: g.dianov@har.mrc.ac.uk

Abbreviations: PARP-1, poly(ADP-ribose) polymerase 1; pADPr, poly(ADP-ribose); 8-oxoguanine, 8-oxo-7,8-dihydroguanine; BER, base excision repair; AP site, apurinic/apyrimidinic site, abasic site; rAP, reduced abasic site; APE1, apurinic/apyrimidinic endonuclease 1; dRP, $5^{\prime}$-deoxyribosephosphate; FEN1, flap endonuclease 1; Pol $\beta$, DNA polymerase $\beta$; dNTPs, deoxyribonucleotide triphosphates; ddNTPs, dideoxyribonucleotide triphosphates; WCE, whole-cell extract.
} 
moval of the modified base by an appropriate glycosylase, generating an $\mathrm{AP}$ site. The $\mathrm{AP}$ site is a substrate for the AP endonuclease, APE1, which incises the backbone $5^{\prime}$ to the abasic site generating a $3^{\prime}$-hydroxyl and a 5 '-deoxyribosephosphate (dRP). In the majority of cases repair then proceeds via short-patch BER (Dianov et al., 1992), in which the $5^{\prime}$-dRP is removed through a $\beta$-elimination reaction catalyzed by polymerase $\beta$ $(\operatorname{Pol} \beta)$, that also inserts a single nucleotide to fill the gap (Matsumoto \& Kim, 1995). Strand integrity is then restored by the action of DNA ligase (Tomkinson \& Levin, 1997). In certain cases, however, the AP site may have been chemically modified such that it is refractory to $\beta$-elimination. In this event repair must then continue down the long-patch pathway in which from 2 to 8 nucleotides are inserted into the repair gap via a strand displacement mechanism (Frosina et al., 1996). The displaced dRP-containing "flap" is then removed by flap endonuclease 1 (FEN1), allowing ligation to proceed (Klungland \& Lindahl, 1997).

The basic enzymology of BER is reasonably well understood and the repair pathways have been reconstituted in vitro using purified enzymes (Klungland \& Lindahl, 1997; Kubota et al., 1996; Matsumoto et al., 1999; Pascucci et al., 1999). However, recent evidence suggests that the precise mechanism of BER may be more complicated, with an increasing number of proteins having been demonstrated to be associated with the repair process (Wood et al., 2001). One such enzyme, poly(ADP-ribose) polymerase-1 (PARP-1), an abundant nuclear enzyme found in multicellular organisms, is thought to be involved in BER (Dantzer et al., 1999) but its precise role remains controversial. PARP-1 binds tightly as a homodimer to both single- and doublestrand breaks. Binding of PARP-1 to a strand break activates its catalytic activity which is to covalently link nuclear proteins with poly(ADP-ribose), pADPr, synthesised from $\mathrm{NAD}^{+}$. One of the main cellular results of this process is an accumulation of negative charge and concomitant loss of affinity of PARP-1 for the DNA strand break (for review see references Althaus \& Richter, 1987; D’Amours et al., 1999).

There is much controversy about the role of PARP-1 in the repair process. PARP-1 null mice are hypersensitive to alkylating agents and irradiation (Ménessier-de Murcia et al., 1997; Wang et al., 1997). Immortalised cells from these animals manifest characteristic features of genomic instability, including delayed rejoining of strand breaks, mixed ploidy and elevated frequencies of SCE and micronuclei formation upon treatment with DNAdamaging agents (Ménessier-de Murcia et al., 1997; Trucco et al., 1998; Wang et al., 1997). Further evidence to suggest a positive role for PARP-1 in BER comes from its ability to interact with other participants in BER including XRCC1 (Caldecott et al., 1996; Masson et al., 1998), and $\operatorname{Pol} \beta$ (Dantzer et al., 2000). In addition, repair of regular AP sites, which is mainly accomplished by short-patch BER, shows a dependence on $\mathrm{NAD}^{+}$(Satoh \& Lindahl, 1992; Satoh et al., 1993). It has been proposed that PARP-1 binds to the incised intermediate and interferes with the repair process: in the absence of $\mathrm{NAD}^{+}$PARP-1 will persist at the strand break and DNA repair will be stalled (Satoh \& Lindahl, 1992; Satoh et al., 1993). In support of this model Vodenicharov et al. (2000) recently demonstrated efficient, $\mathrm{NAD}^{+}$-independent repair of single-strand breaks and alkylated bases by extracts of cells from PARP-1 deficient mice.

However, Dantzer et al. (2000) reported that cells deficient in PARP-1 show a moderate defect in short-patch repair of AP sites but are almost totally incapable of performing longpatch BER suggesting an active role for PARP-1 in DNA damage processing.

We have recently developed a cell-free assay which allows us to monitor the progress of BER at single nucleotide resolution and to differentiate between the short- and long-patch pathways (Allinson et al., 2001). This assay has been used to study the NAD ${ }^{+}$and PARP-1- 
dependence of both short-and long-patch BER of AP-site containing substrates.

\section{MATERIALS AND METHODS}

Materials. The 8-oxoguanine-containing synthetic oligodeoxyribonucleotide, purified by high-performance liquid chromatography, was obtained from Midland. [ $\gamma_{-}{ }^{32}$ P]ATP (3000 $\mathrm{Ci} / \mathrm{mmol}$ ) was purchased from NEN Life Science Products. Recombinant human PARP-1 was obtained from Alexis Biochemicals. Mouse 8-oxoguanine-DNA glycosylase (mOGG1) was a gift from Dr. D. Zharkov.

Preparation of substrate. Oligonucleotide 5'-ATATACCGCG[8-oxo]GCCGATCAAGCT TATT-3' (30 pmol) was 5'-end labeled with $100 \mu \mathrm{Ci}$ (33 pmol) of $\left[\gamma_{-}{ }^{32} \mathrm{P}\right]$-ATP and used for construction of a substrate containing a single 8-oxoguanine in circular closed doublestranded DNA as previously described (Dianov et al., 1998). This substrate was converted to AP-site containing substrate by incubating $2 \mathrm{nM}$ substrate with $25 \mathrm{nM}$ OGG1 for $20 \mathrm{~min}$ at $37^{\circ} \mathrm{C}$ in buffer containing $50 \mathrm{mM}$ Hepes/KOH, pH 7.8, $50 \mathrm{mM} \mathrm{KCl,} 10 \mathrm{mM}$ $\mathrm{MgCl}_{2}, \quad 0.5 \mathrm{mM}$ EDTA and $1.5 \mathrm{mM}$ dithiothreitol (DTT).

Cells and extracts. Mouse embryonic fibroblasts derived from normal and PARP-1 knockout mice were kindly provided by Dr. G. de Murcia. Cells were maintained in DMEM medium supplemented with $10 \%$ foetal bovine serum and antibiotics. Whole-cell extracts were prepared by the method of Tanaka et al. (1992) as modified by Vodenicharov et al. (2000) and dialysed overnight against buffer containing $25 \mathrm{mM}$ Hepes/KOH, pH 7.9, $2 \mathrm{mM}$ DTT, $12 \mathrm{mM}$ $\mathrm{MgCl}_{2}, 0.1 \mathrm{mM}$ EDTA, $17 \%$ glycerol and $0.1 \mathrm{M}$ $\mathrm{KCl}$. Extracts were aliquoted and stored at $-80^{\circ} \mathrm{C}$.

BER reactions. The $\mathrm{BER}$ reactions were carried out in a reaction mixture $(50 \mu \mathrm{l})$ containing $50 \mathrm{mM}$ Hepes/KOH, pH 7.8, $50 \mathrm{mM}$ $\mathrm{KCl}, 10 \mathrm{mM} \mathrm{MgCl} 2,0.5 \mathrm{mM}$ EDTA, $1.5 \mathrm{mM}$
DTT, $2 \mathrm{mM}$ ATP, $0.4 \mathrm{mg} / \mathrm{ml}$ bovine serum albumin (BSA), $25 \mathrm{mM}$ phosphocreatine (di-Tris salt, Sigma), $2.5 \mu \mathrm{g}$ creatine phosphokinase (type I, Sigma), 8.5\% glycerol (Fluka), $20 \mu \mathrm{M}$ each of the indicated dNTPs or ddNTPs, $100 \mathrm{ng}$ ( $20 \mathrm{fmol}$ ) of ${ }^{32} \mathrm{P}$-labeled single 8-oxoguanine containing DNA substrate, $400 \mathrm{ng}$ of carrier plasmid DNA (pUC18) and, where applicable, $0.25 \mathrm{mM} \mathrm{NAD}^{+}$. Reactions were initiated by the addition of whole-cell extract $(100 \mu \mathrm{g})$ and incubated for the indicated time at $37^{\circ} \mathrm{C}$. The reactions were stopped by addition of $40 \mu \mathrm{l}$ of the reaction mix to $2 \mu \mathrm{l}$ of $0.5 \mathrm{M}$ EDTA, $2 \mu \mathrm{l}$ of $10 \% \mathrm{SDS}$, and $2 \mu \mathrm{l}$ of Proteinase K ( $5 \mathrm{mg} / \mathrm{ml})$. After incubation for 30 min at $37^{\circ} \mathrm{C}$, substrate DNA was purified from the reaction mixture by phenol-chloroform extraction and filtered through a Sepharose-G25 spin column equilibrated with 10 $\mathrm{mM}$ Tris/HCl, $\mathrm{pH}$ 8.0. Filtrates were spindried, dissolved in appropriate restriction buffers supplied by the manufacturer and treated with 10-40 units of the indicated restriction endonuclease(s) for $1 \mathrm{~h}$ at $37^{\circ} \mathrm{C}$. An equal volume of gel loading buffer (95\% formamide, $20 \mathrm{mM}$ EDTA, $0.02 \%$ bromophenol blue, and $0.02 \%$ xylene cyanol) was then added, and following incubation at $90^{\circ} \mathrm{C}$ for $3 \mathrm{~min}$ the products were separated by electrophoresis in a $10 \%$ polyacrylamide gel containing $7 \mathrm{M}$ urea in $89 \mathrm{mM}$ Tris $/ \mathrm{HCl}, 89 \mathrm{mM}$ boric acid, and $2 \mathrm{mM}$ EDTA, $\mathrm{pH}$ 8.0.

All experiments were repeated at least 3 times and phosphorimages of representative gels are shown. Gels were analysed using Quantity One software (Bio-Rad).

\section{RESULTS}

\section{Substrate characterization}

A single AP site-containing closed circular DNA substrate was generated from 8-oxoguanine-containing substrate by treatment with 8-oxoguanine-DNA glycosylase (OGG1). The substrate DNA was designed so that the 
AP site and an upstream ${ }^{32} \mathrm{P}$ label were located within a 59-mer HindIII restriction fragment (Fig. 1A). The AP site was positioned within one of two HaeIII recognition sequences, effectively blocking HaeIII cleavage at this site until its repair. The substrate was carefully charac- both HindIII and HaeIII yielded a 52-mer fragment, confirming that the presence of the AP site did indeed block cleavage of one of the HaeIII sites (Fig. 1B, lane 3). Restoration of this HaeIII site by repair would result in a 48-mer fragment being generated by HindIII/
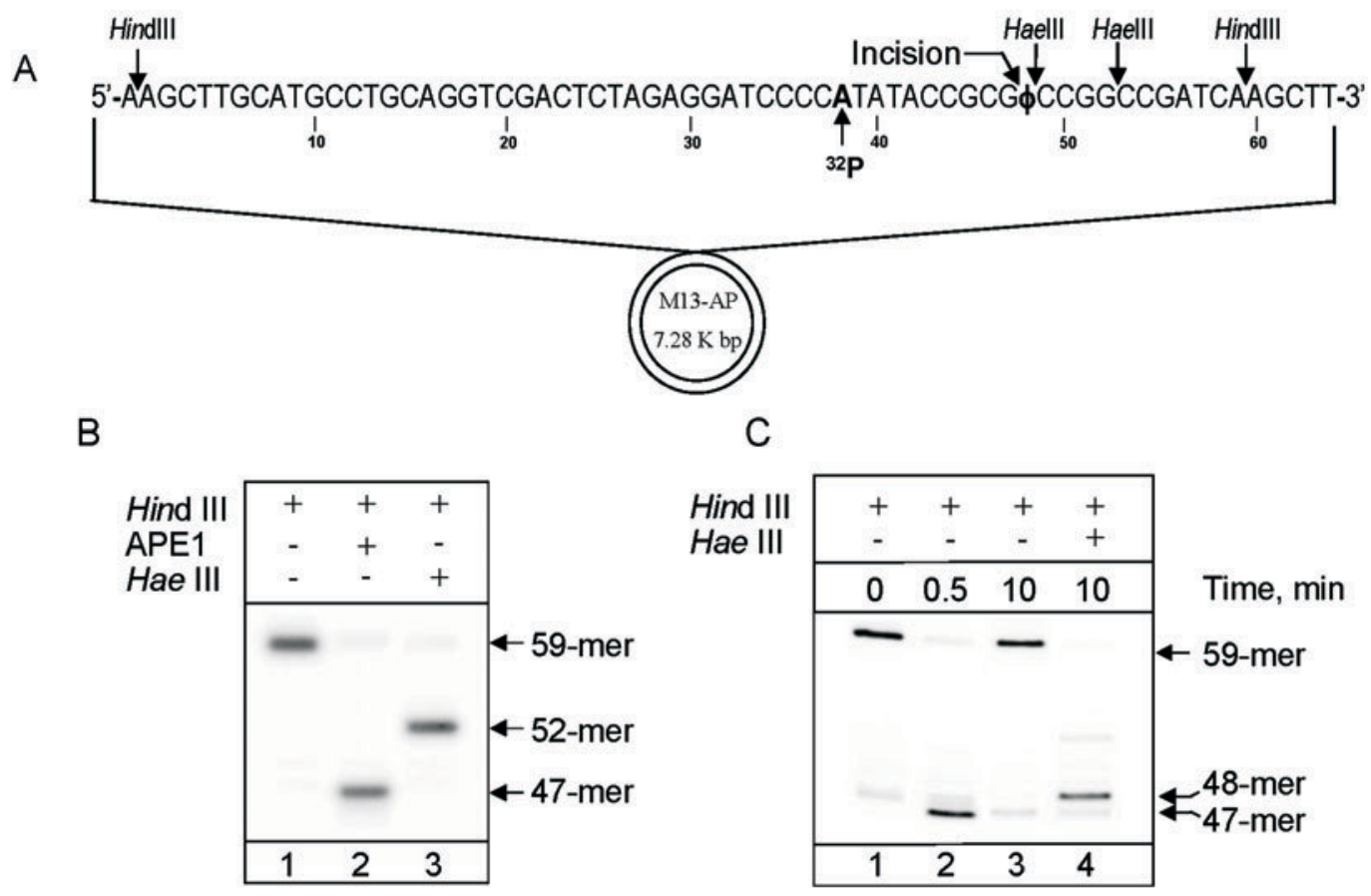

Figure 1. Substrate design and characterisation.

(A) Schematic presentation of the AP site-containing substrate. The AP site is indicated by $\phi$. The sites of cleavage by the restriction enzymes, HindIII and HaeIII and the position of the ${ }^{32} \mathrm{P}$ label are shown. The site of incision by AP endonuclease is indicated with an arrow. (B) Characterisation of the AP site-containing substrate. Digestion of the AP substrate with HindIII (lane 1), HindIII and APE1 (lane 2) and HindIII and HaeIII (lane 3). Products were analysed by electrophoresis in a 10\% denaturing polyacrylamide gel. (C) Rapid cleavage of substrate by APE. Reaction mixtures $(50 \mu \mathrm{l})$ contained $100 \mathrm{ng}$ of AP site-containing substrate DNA, $100 \mu \mathrm{g}$ of PARP- ${ }^{+/+}$WCE and $0.25 \mathrm{mM}$ $\mathrm{NAD}^{+}$and were incubated at $37^{\circ} \mathrm{C}$ for the indicated times. Reactions were quenched by addition of $2 \mu \mathrm{l}$ of $0.5 \mathrm{M}$ EDTA and $2 \mu \mathrm{l}$ of $10 \%$ SDS. For the 0 min time point the EDTA and SDS were added to the WCE immediately prior to addition of the substrate. The substrate was purified, treated with $20 \mathrm{mM} \mathrm{NaBH}_{4}$ to stabilize the AP sites to electrophoresis and then digested with either HindIII (lanes 1-3) or HindIII and HaeIII (lane 4). Products were analysed as in Fig. 1B.

terized prior to use. Treatment of the substrate with HindIII generated only a 59-mer labeled DNA fragment (Fig. 1B, lane 1), confirming that the lyase activity of OGG1 had not cleaved the AP site. The presence of the AP site was verified by treatment of the substrate with both HindIII and APE1, which generated the expected 47-mer fragment (Fig. 1B, lane 2). Finally, double digestion of the substrate with
HaeIII double digestion.

Initial experiments showed that the activity of AP endonuclease in all cell extracts used was so high that all the substrate was cleaved at the AP site before the earliest measurable time point of $30 \mathrm{~s}$ (Fig. 1C, lane 2). Therefore, in practice any 59-mer observed in the HindIII digests was due to fully repaired reaction products, as confirmed by conversion of this 
59-mer to 48-mer on treatment with HaeIII (Fig. 1C, lanes 3 and 4). Thus, repair progress could be monitored by accumulation of 59-mer in the HindIII digests, and for simplicity all the remaining figures show only the HindIII digests although double digests were carried out in each case.

\section{$\mathrm{NAD}^{+}$is required for repair of abasic sites through both short- and long-patch BER pathways}

Whole-cell extracts used in our assay are nearly completely depleted of $\mathrm{NAD}^{+}$(Vodenicharov et al., 2000) and thus suitable to study the effect of $\mathrm{NAD}^{+}$on the repair process. The stimulatory effect of $\mathrm{NAD}^{+}$on short-patch $\mathrm{BER}$, involved in repair of DNA base damages and regular AP sites, is well established, and it is widely accepted that $\mathrm{NAD}^{+}$stimulates release of PARP-1 from the complex with nicked DNA (D'Amours et al., 1999). However, little is known on the effect of $\mathrm{NAD}^{+}$on long-patch $\mathrm{BER}$, which is involved in repair of AP sites that are resistant to $\beta$-elimination, and, therefore, cannot be processed via short-patch BER.

Whole cell extracts derived from normal mouse embryonic fibroblasts $\left(\mathrm{PARP}-1^{+/+}\right.$
WCE), supplemented or non-supplemented with $\mathrm{NAD}^{+}$, were incubated with the regular AP site-containing substrate (Fig. 2). Although, as previously discussed, APE1 cleavage of the substrate was very rapid, in the absence of $\mathrm{NAD}^{+}$repair was relatively slow, proceeding to $84 \%$ completion, as judged by accumulation of the 59-mer fragment following HindIII digestion, only after 60 minutes' incubation (Fig. 2A, lanes 1 to 3 ). When $\mathrm{NAD}^{+}$was added to the reaction mix, the rate of the repair reaction was greatly increased, with $97 \%$ of the substrate being completely repaired within $30 \mathrm{~min}$ (Fig. 2A, lanes 4 to 6), and an approximately 4 -fold increase in maximal repair rate (Fig. 2B).

Similar experiments were performed with the substrate containing a reduced AP site (rAP). To confirm that our substrate containing a rAP site was repaired only through long-patch BER, we first carried out the repair reaction under conditions allowing only short-patch synthesis (Allinson et al., 2001). Briefly, this involves limiting the pool of nucleotides available for repair synthesis to dGTP only, with all other nucleotides being present as dideoxyribonucleotide triphosphates (ddNTP). Following insertion of the first nucleotide (dGTP), repair may only pro-
A

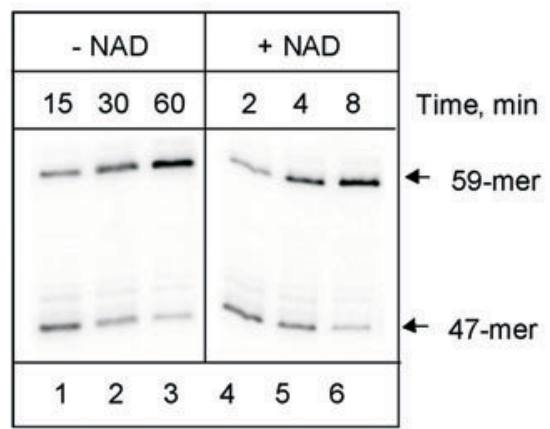

B

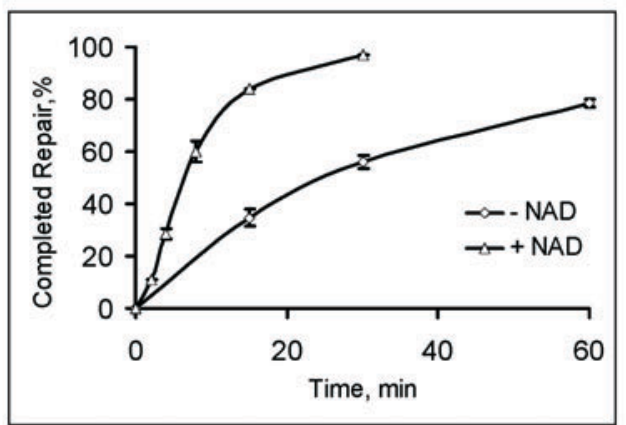

Figure 2. Repair of a regular AP site-containing substrate by $\mathrm{PARP}^{+1^{+/}}$cell extracts.

(A) Kinetics of repair of AP site in the absence (lanes 1-3) and presence (lanes 4-6) of NAD ${ }^{+}$. Reaction mixtures (50 $\mu \mathrm{l})$ contained $100 \mathrm{ng}$ of substrate DNA, $100 \mu \mathrm{g}$ of PARP- $1^{+/+} \mathrm{WCE}$ and, where applicable, $0.25 \mathrm{mM} \mathrm{NAD}{ }^{+}$. Reactions were incubated at $37^{\circ} \mathrm{C}$ for the indicated time periods. The substrate DNA was subsequently purified and then treated with HindIII. Products were analysed as in Fig. 1B. (B) Comparative plots for repair progress in the presence and absence of $\mathrm{NAD}^{+}$are shown, and the amount repaired is calculated as the percentage of 59-mer present after HindIII cleavage. Error bars show the standard deviation. 
ceed to completion via removal of the deoxyribose phosphate moiety by the $\mathrm{dRP}$ lyase activity of polymerase $\beta$ and subsequent ligation (i.e., via the short-patch mechanism). If long-patch repair is involved, then a second nucleotide (ddNTP) will be inserted and further repair synthesis/ligation will be blocked, resulting in accumulation of a 49-mer product following HindIII hydrolysis of the substrate DNA. Under these conditions the regular AP

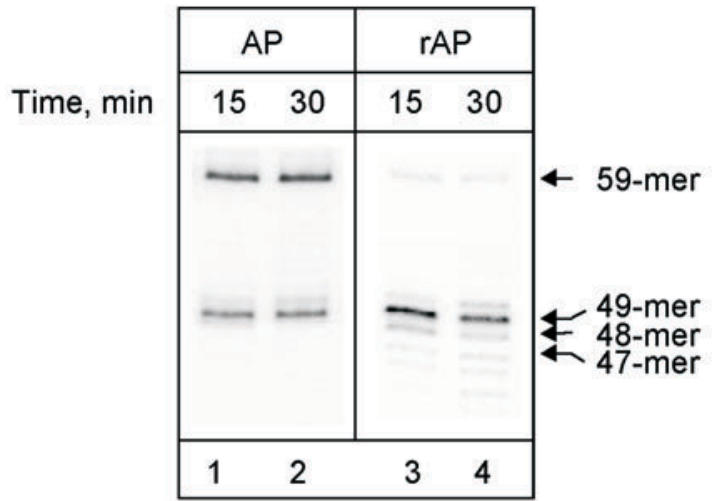

Figure 3. Repair of normal and reduced AP site-containing substrates under "short-patch" conditions.

Reaction mixtures containing $100 \mathrm{ng}$ of substrate DNA, $100 \mu \mathrm{g}$ of PARP- $1^{+/+}$WCE, $0.25 \mathrm{mM} \mathrm{NAD}^{+}$and $20 \mu \mathrm{M}$ dGTP, ddATP, ddCTP and ddTTP were incubated at $37^{\circ} \mathrm{C}$ for the indicated time periods. The substrate DNA was subsequently purified and then treated with HindIII. Products were analysed as in Fig. 1B. site was efficiently repaired (Fig. 3, lanes 1 and 2), but repair of the rAP substrate was unable to proceed beyond the polymerase step (Fig. 3, lanes 3 and 4). As expected, repair terminated following the incorporation of ddNTPs, forming a non-processable species which was subject to subsequent slight nucleolytic degradation (seen as <47-mers (Fig. 3, lanes 3 and 4)).

Having confirmed that the rAP substrate could only be repaired via the long-patch pathway, we then applied this substrate to studying long-patch BER by PARP-1 ${ }^{+/+}$WCE both in the presence and absence of $\mathrm{NAD}^{+}$. Under these conditions slightly reduced rates of repair were observed relative to the corresponding rates for the AP substrate. However, the stimulation of repair rate by $\mathrm{NAD}^{+}$was of a similar magnitude (6-fold) to that previously observed for a regular AP-site containing substrate (Fig. 4).

\section{PARP-1 reduces the efficiency of both short- and long-patch BER}

While the data above showed that $\mathrm{NAD}^{+}$is able to stimulate both short- and long-patch repair to approximately equal extents, we were unable to conclude whether PARP-1 plays a
A

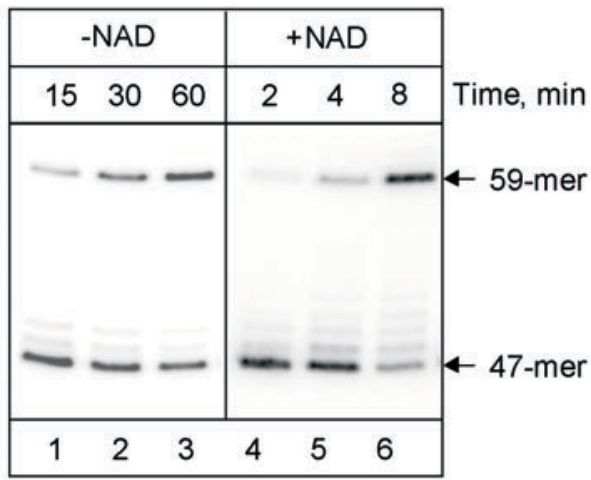

B

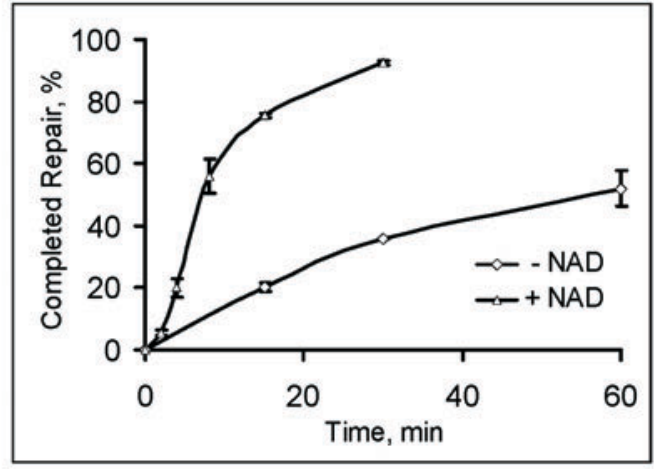

Figure 4. Repair of a reduced AP site-containing substrate.

(A) Reaction mixtures $(50 \mu \mathrm{l})$ containing $100 \mathrm{ng}$ of substrate DNA, $100 \mu \mathrm{g}$ of PARP- $1^{+/+} \mathrm{WCE}, 20 \mu \mathrm{M}$ dNTPs and, where applicable, $0.25 \mathrm{mM} \mathrm{NAD}^{+}$were incubated at $37^{\circ} \mathrm{C}$ for the indicated time periods. The substrate DNA was subsequently purified and then treated with HindIII. Products were analysed as in Fig. 1B. (B) Comparative plots for repair progress in the presence and absence of $\mathrm{NAD}^{+}$are shown and the amount repaired and designations as in Fig. 2B. 
positive, accessory role in BER or whether, as proposed by Satoh \& Lindahl (1992), its effect is negative and inhibitory. We addressed this question by measuring repair rates for both regular and reduced AP sites in extracts derived from PARP-1-knockout cells (PARP-1 ${ }^{-/-}$ WCE). Western blot analysis confirmed the absence of PARP-1 protein in these extracts (not shown). Incubation of the AP site-containing substrate with PARP-1 ${ }^{-/-}$WCE led to complete repair of $87 \%$ of the substrate in two minutes with or without $\mathrm{NAD}^{+}$(Fig. $5 \mathrm{~A}$ and $\mathrm{B}$ ) in comparison to $60 \%$ repair in $8 \mathrm{~min}$ when in- nant PARP-1 was titrated into PARP-1 ${ }^{-/-}$ WCE. Since it has been reported (Satoh et al., 1994; Vodenicharov et al., 2000) that PARP $-1{ }^{+/+}$WCE contains PARP-1 at approximately $1.5-2 \mu \mathrm{g}$ per mg of extract, we added 30, 150 and $750 \mathrm{ng}$ of PARP-1 to PARP-1 ${ }^{-/-}$ WCE and measured the amount of AP substrate repaired. We established that in the presence of $\mathrm{NAD}^{+}$, PARP-1 had a concentration-dependent inhibitory effect on repair by PARP-1 ${ }^{-/-}$WCE, the major repair intermediate being the 47-mer APE1 incision product (Fig. 7).
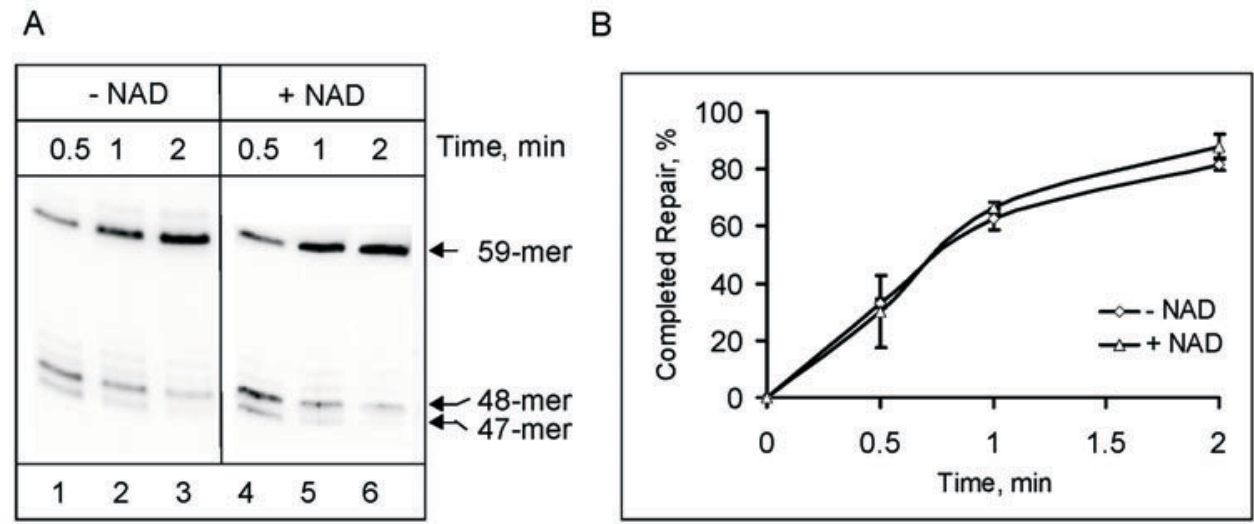

Figure 5. Characterisation of abasic site repair by PARP-1-deficient cell extracts.

(A) Kinetics of repair of AP site in the absence and presence of $\mathrm{NAD}^{+}$by PARP- $1^{-/-}$WCE. Reaction mixtures (50 $\mu \mathrm{l}$ ) contained $100 \mathrm{ng}$ of substrate DNA, $100 \mu \mathrm{g}$ of PARP-1 ${ }^{-/}$WCE and, where applicable, $0.25 \mathrm{mM} \mathrm{NAD}^{+}$. Reactions were incubated at $37^{\circ} \mathrm{C}$ for the indicated time periods. The substrate DNA was subsequently purified and then treated with HindIII. Products were analysed as in Fig. 1B. (B) Comparative plots for repair progress in the presence and absence of $\mathrm{NAD}^{+}$are shown, and the amount repaired and designations as in Fig. $2 \mathrm{~B}$.

cubated with PARP- $1^{+/+}$WCE in the presence of $\mathrm{NAD}^{+}$(Fig. 2). PARP-1 deficient extracts also efficiently repaired the rAP site-containing substrate and repair was likewise $\mathrm{NAD}^{+}$-independent. Within 8 min $94 \%$ was repaired (Fig. 6) in comparison to $56 \%$ when incubated with PARP- $1^{+/+}$WCE in the presence of $\mathrm{NAD}^{+}$(Fig. 4).

\section{Inhibition of AP-site repair by recombinant human PARP}

In order to assess whether the increased rate of repair in $\mathrm{PARP}^{-/-}$WCE reflected a PARP-1 inhibitory effect, purified recombi-

\section{DISCUSSION}

Since the discovery that stimulation of strand break repair by $\mathrm{NAD}^{+}$was attributable to the poly(ADP-ribosyl)ation activity of PARP-1 (Satoh \& Lindahl, 1992), much evidence suggested that PARP-1 affects BER. Following their initial findings, Satoh and Lindahl proposed a mechanism whereby PARP-1 inhibited the progress of BER by binding to a repair intermediate, protecting it from nucleases and recombination enzymes, but at the same time blocking access by components of the BER machinery (Satoh \& Lindahl, 1992). According to this model, mod- 
A

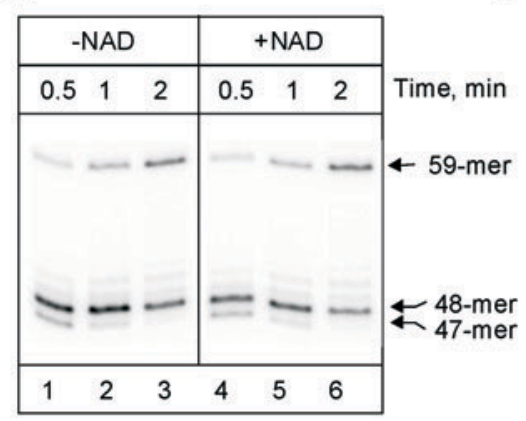

B

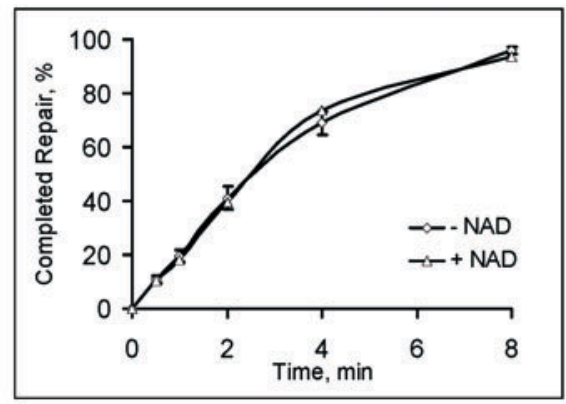

Figure 6. Repair of a reduced abasic site by PARP-1-deficient cell extracts.

(A) Reaction mixtures $\left(50 \mu \mathrm{l}\right.$ ) containing $100 \mathrm{ng}$ of substrate DNA, $100 \mu \mathrm{g}$ of PARP- $1^{-/-} \mathrm{WCE}, 20 \mu \mathrm{M}$ dNTPs and, where applicable, $0.25 \mathrm{mM} \mathrm{NAD}^{+}$were incubated at $37^{\circ} \mathrm{C}$ for the indicated time periods. The substrate DNA was subsequently purified and then treated with HindIII. Products were analysed as in Fig. 1B. (B) Comparative plots for repair progress in the presence and absence of $\mathrm{NAD}^{+}$are shown, and the amount repaired and designations as in Fig. $2 \mathrm{~B}$.

ification of PARP-1 with pADPr synthesised from $\mathrm{NAD}^{+}$leads to its dissociation from the repair site, allowing access of other enzymes. An alternative theory, that PARP-1 plays an active role in recruiting enzymes to the repair site, has since been advanced and supported by the finding that PARP-1 is able to interact the absence of $\mathrm{NAD}^{+}$(Prasad et al., 2001). Additionally, Dantzer et al. (2000) recently reported that extracts from PARP-1 ${ }^{-/-}$cells were significantly inhibited in repair synthesis at AP sites, with the long-patch contribution to repair being particularly affected. However, a contradictory almost simulta-
A

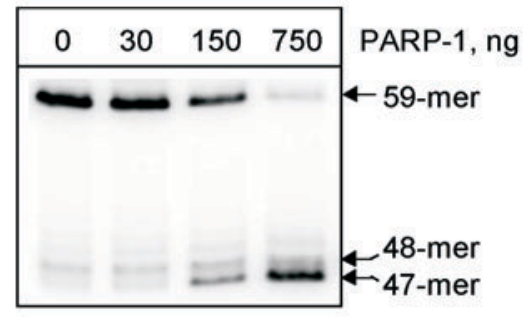

B

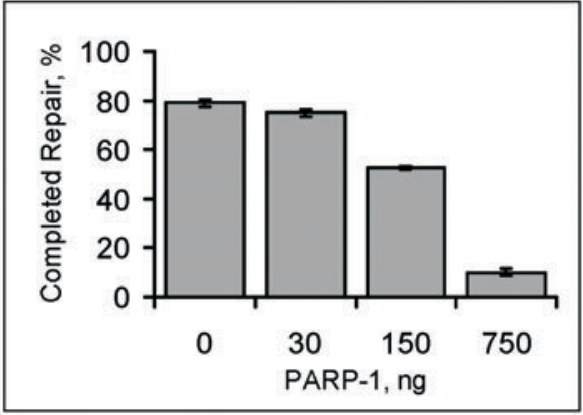

Figure 7. Titration of purified PARP-1 into PARP-1 deficient cell extracts.

(A) Reaction mixtures (50 $\mu \mathrm{l}$ ) containing $100 \mathrm{ng}$ of AP substrate DNA, $100 \mu \mathrm{g}$ of PARP-1 ${ }^{-/-} \mathrm{WCE}, 20 \mu \mathrm{M}$ dNTPs, $0.25 \mathrm{mM} \mathrm{NAD}^{+}$and the indicated amount of PARP- 1 were incubated at $37^{\circ} \mathrm{C}$ for $2 \mathrm{~min}$. The substrate DNA was subsequently purified and then treated with HindIII. Products were analysed as in Fig. 1B. (B) Repair efficiency on addition of varying amounts of PARP-1. The amount repaired and designations as in Fig. 2B.

with the BER enzymes, XRCC1 (Caldecott et al., 1996; Masson et al., 1998) and Pol $\beta$ (Dantzer et al., 2000). Experiments carried out with purified recombinant enzymes have shown that PARP-1 is able to stimulate strand displacement synthesis by $\mathrm{Pol} \beta$ but only in neous report by Vodenicharov et al. (2000) demonstrated efficient repair by $\mathrm{PARP}-1^{-/-}$ WCE of DNA damaged by ionizing radiation or an alkylating agent. This discrepancy of views led us to apply our recently developed in vitro DNA repair assay (Allinson et al., 2001), 
measuring the number of repair events rather then incorporation of labeled dNTPs during repair, to further examine the participation of both PARP-1 and pADPr synthesis in the short- and long-patch BER sub-pathways.

We found that repair of both regular and reduced AP sites was stimulated 4-6-fold by the presence of $\mathrm{NAD}^{+}$, with the major repair intermediate being the nicked AP site (Fig. 2, 47-mer). This result suggested that PARP-1 is able to efficiently displace APE1 from the repair site and may therefore have to be incorporated into the 'passing-the-baton' model of base excision repair (Wilson \& Kunkel, 2000). According to this model, repair proteins sequentially pass repair intermediates from one enzyme to another without leaving the repair site unattended at any time. It is also suggested that after incision of an AP site, APE1 remains bound to it and is substituted by DNA polymerase $\beta$. However, our results clearly indicate that PARP-1 always binds to the nicked $\mathrm{AP}$ site before $\mathrm{Pol} \beta$ and must be released from the site for repair to continue. The delayed repair in the absence of $\mathrm{NAD}^{+}$observed in our experiments most probably results from spontaneous dissociation of PARP-1 from the nicked site.

Surprisingly, we found that the repair rates for both an AP and an rAP site were actually increased in $\mathrm{PARP}-1^{-/-} \mathrm{WCE}$ relative to those for PARP-1 ${ }^{+/+}$WCE complemented with $\mathrm{NAD}^{+}$(Figs. 5 and 6), suggesting that PARP-1 actively slows down the progress of both BER sub-pathways even in the presence of $\mathrm{NAD}^{+}$. This was further confirmed by the titration of purified recombinant PARP-1 into $\mathrm{PARP}^{-1}{ }^{-/}$WCE complemented with $\mathrm{NAD}^{+}$. We found that addition of PARP-1 to PARP- $1^{-/}$WCE led to a decrease in repair rate (Fig. 7).

The repair rate of both substrates by PARP-1 ${ }^{-/-}$WCE was unaffected by $\mathrm{NAD}^{+}$, in agreement with the results obtained by Vodenicharov et al. (2000). Moreover, the rate-limiting step of the repair process in the two different extracts is different. In
PARP $-1^{+/+}$extracts, repair is delayed after APE1 incision and is presumably limited by the accessibility of the repair site to $\operatorname{Pol} \beta$ due to the presence of PARP-1. In PARP-1 ${ }^{-/-}$extracts, the major repair intermediate is the product of insertion of a single nucleotide at the repair site (Fig. 6, 48-mer). For a regular AP site, it is likely that the rate-limiting step in $\mathrm{PARP}-1^{-/}$extracts is the removal of the $\mathrm{dRP}$ moiety, because for repair of an AP site in the absence of PARP-1, dRP removal was reported to be the rate-limiting step (Srivastava et al., 1998).

It was initially puzzling as to why our results should contrast so sharply with those of Dantzer et al. (2000). However, their experimental approach was based on quantitating nucleotide incorporation rather than monitoring of actual repair rates. Sanderson \& Lindahl (2002) recently demonstrated reduced levels of FEN1 in PARP-1 ${ }^{-/}$cell extracts. They proposed that if the repair patch size is increased for long-patch repair in PARP- $1^{+/+}$extracts versus $\mathrm{PARP}-1^{-/-}$extracts, then more nucleotides will be incorporated per repair event and repair will appear more efficient in PARP- $1^{+/+}$extracts.

It is, however, unquestionable that PARP-1 is somehow involved in the mechanism of BER. If this involvement does not improve the efficiency of repair, then why should such a $\mathrm{NAD}^{+}$depleting process occur? Vodenicharov et al. (2000) have speculated that the hypersensitivity of PARP-1 ${ }^{-/-}$mice and cells to ionizing radiation and alkylating agents may be due to greatly reduced levels of poly(ADPribosyl)ation of other cellular targets (Vodenicharov et al., 2000), rather than a defect in base excision repair per se. This could also explain why PARP-1 $1^{-/-}$cell lines recapitulate the genomic instability effects of PARP inhibitors (Oikawa et al., 1980) or expression of a dominant negative mutant (Kupper et al., 1995; Molinete et al., 1993; Schreiber et al., 1995). PARP-1 and poly(ADP-ribosyl)ation reactions have been implicated in a wide range of cellular processes such as transcriptional 
control, chromatin re-modelling and signalling (reviewed in de Murcia \& Shall, 2000). Our data lend further support to the theory that the main role of PARP-1 in BER does not lie in direct catalysis of DNA damage processing, but instead in linking repair and these processes.

Helen Budworth and Kate Sleeth are thanked for critical reading of the manuscript. We are grateful to Dmitry Zharkov and Gilbert de Murcia for providing mouse 8-oxoguanine-DNA glycosylase and PARP-1-knockout cells, respectively.

\section{R E F E R E N C E S}

Allinson SL, Dianova II, Dianov GL. (2001) DNA polymerase beta is the major dRP lyase involved in repair of oxidative base lesions in DNA by mammalian cell extracts. EMBO J.; 20: 6919-26.

Althaus FR, Richter C. (1987) ADP-ribosylation of proteins - Enzymology and biological significance. Springer-Verlag Berlin.

Caldecott KW, Aoufouchi S, Johnson P, Shall S. (1996) XRCC1 polypeptide interacts with DNA polymerase beta and possibly poly(ADP-ribose) polymerase and DNA ligase III is a novel molecular 'nick-sensor' in vitro. Nucleic Acids Res.; 24: 4387-94.

D’Amours D, Desnoyers S, D'Silva I, Poirier GG. (1999) Poly(ADP-ribosyl)ation reactions in the regulation of nuclear functions. Biochem J.; 342: 249-68.

Dantzer F, Schreiber V, Niedergang C, Trucco C, Flatter E, De la Rubia G, Oliver J, Rolli V, Menissier-de Murcia J, de Murcia G. (1999) Involvement of poly(ADP-ribose) polymerase in base excision repair. Biochimie.; 81: $69-75$.

Dantzer F, de la Rubia G, Menessier-de Murcia J, Hostomsky Z, de Murcia G, Schreiber V. (2000) Base excision repair is impaired in mammalian cells lacking poly(ADP-ribose) polymerase-1. Biochemistry.; 39: 7559-69. de Murcia G, Shall S. (2000) Poly(ADP-ribosylation) reactions from DNA damage and stress signalling to cell death. Oxford University Press.

Dianov G, Price A, Lindahl T. (1992) Generation of single-nucleotide repair patches following excision of uracil residues from DNA. Mol Cell Biol.; 12: 1605-12.

Dianov G, Bischoff C, Piotrowski J, Bohr VA. (1998) Repair pathways for processing of 8-oxoguanine in DNA by mammalian cell extracts. J Biol Chem.; 273: 33811-6.

Frosina G, Fortini P, Rossi O, Carrozzino F, Raspaglio G, Cox LS, Lane DP, Abbondandolo A, Dogliotti E. (1996) Two pathways for base excision repair in mammalian cells. J Biol Chem.; 271: 9573-8.

Klungland A, Lindahl T. (1997) Second pathway for completion of human DNA base excisionrepair: reconstitution with purified proteins and requirement for DNase IV (FEN1). EMBO J.; 16: 3341-8.

Kubota Y, Nash RA, Klungland A, Schar P, Barnes DE, Lindahl T. (1996) Reconstitution of DNA base excision-repair with purified human proteins: interaction between DNA polymerase beta and the XRCC1 protein. EMBO J.; 15: 6662-70.

Kupper JH, Muller M, Jacobson MK, TatsumiMiyajima J, Coyle DL, Jacobson EL, Burkle A. (1995) Transdominant inhibition of poly(ADP-ribosyl)ation sensitizes cells against gamma-irradiation and $N$-methyl- $N^{\prime}$-nitro- $N$-nitrosoguanidine but does not limit DNA-replication of a polyomavirus replicon. Mol Cell Biol.; 15: 3154-63.

Lindahl T. (1993) Instability and decay of the primary structure of DNA. Nature.; 362: 709-15.

Masson M, Niedergang C, Schreiber V, Muller S, Menissier-de Murcia J, de Murcia G. (1998) $\mathrm{XRCC} 1$ is specifically associated with poly(ADP-ribose) polymerase and negatively regulates its activity following DNA damage. Mol Cell Biol.; 18: 3563-71.

Matsumoto Y, Kim K. (1995) Excision of deoxyribose phosphate residues by DNA poly- 
merase $\beta$ during DNA repair. Science.; 269: 699-702.

Matsumoto Y, Kim K, Hurwitz J, Gary R, Levin DS, Tomkinson AE, Park MS. (1999) Reconstitution of proliferating cell nuclear antigen-dependent repair of apurinic/apyrimidinic sites with purified human proteins. $J$ Biol Chem.; 274: 33703-8.

Ménessier-de Murcia J, Niedergang C, Trucco C, Ricoul M, Dutrillaux B, Mark M, Oliver FJ, Masson M, Dierich A, LeMeur M, Walztinger C, Chambon P, de Murcia G. (1997) Requirement of poly(ADP-ribose) polymerase in recovery from DNA damage in mice and in cells. Proc Natl Acad Sci U S A.; 94: 7303-7.

Molinete M, Vermeulen W, Burkle A, Menissier-de Murcia J, Kupper JH, Hoeijmakers JHJ, de Murcia G. (1993) Overproduction of the poly(ADP-ribose) polymerase DNA-binding domain blocks alkylation-induced DNA-repair synthesis in mammalian cells. EMBO J.; 12: 2109-17.

Oikawa A, Tohda H, Kanai M, Miwa M, Sugimura T. (1980) Inhibitors of poly(adenosine diphosphate ribose) polymerase induce sister chromatid exchanges. Biochem Biophys Res Commun.; 97: 1311-6.

Pascucci B, Stucki M, Jonsson ZO, Dogliotti E, Hubscher U. (1999) Long patch base excision repair with purified human proteins - DNA ligase I as patch size mediator for DNA polymerases delta and epsilon. J Biol Chem.; 274: 33696-702.

Prasad R, Lavrik OI, Kim SJ, Kedar P, Yang XP, van de Berg BJ, Wilson SH. (2001) DNA polymerase beta-mediated long patch base excision repair - Poly(ADP-ribose) polymerase-1 stimulates strand displacement DNA synthesis. J Biol Chem.; 276: 32411-4.

Sanderson RJ, Lindahl T. (2002) Down-regulation of DNA repair synthesis at DNA single-strand interruptions in poly(ADP-ribose) polymerase-1 deficient murine cell extracts. DNA Repair.; 1: 547-58.

Satoh MS, Lindahl T. (1992) Role of poly(ADP-ribose) formation in DNA repair. Nature.; 356: 356-8.
Satoh MS, Poirier GG, Lindahl T. (1993) $\mathrm{NAD}^{+}$-dependent repair of damaged DNA by human cell-extracts. J Biol Chem.; 268: 5480-7.

Satoh MS, Poirier GG, Lindahl T. (1994) Dual function for poly(ADP-ribose) synthesis in response to DNA strand breakage. Biochemistry.; 33: 7099-106.

Schreiber V, Hunting D, Trucco C, Gowans B, Grunwald D, de Murcia G, Menessier-de Murcia J. (1995) A dominant-negative mutant of human poly(ADP-ribose) polymerase affects cell recovery apoptosis and sister-chromatid exchange following DNA damage. Proc Natl Acad Sci U S A.; 92: 4753-7.

Srivastava DK, van de Berg BJ, Prasad R, Molina JT, Beard WA, Tomkinson AE, Wilson SH. (1998) Mammalian abasic site base excision repair - identification of the reaction sequence and rate-determining steps. $J$ Biol Chem.; 273: 21203-9.

Tanaka M, Lai JS, Herr W. (1992) Promoter-selective activation domains in Oct-1 and Oct-2 direct differential activation of an SnRNA and messenger-RNA promoter. Cell.; 68: $755-67$.

Tomkinson AE, Levin DS. (1997) Mammalian DNA ligases. Bioessays.; 19: 893-901.

Trucco C, Oliver FJ, de Murcia G, Menissier-de Murcia J. (1998) DNA repair defect in poly(ADP-ribose) polymerase-deficient cell lines. Nucleic Acids Res.; 26: 2644-9.

Vodenicharov MD, Sallmann FR, Satoh MS, Poirier GG. (2000) Base excision repair is efficient in cells lacking poly(ADP- ribose) polymerase 1. Nucleic Acids Res.; 28: 3887-96.

Wang ZQ, Stingl L, Morrison C, Jantsch M, Los M, SchulzeOsthoff K, Wagner EF. (1997) PARP is important for genomic stability but dispensable in apoptosis. Genes Dev.; 11: 2347-58.

Wilson SH, Kunkel TA. (2000) Passing the baton in base excision repair. Nat Struct Biol.; 7: $176-8$.

Wood RD, Mitchell M, Sgouros J, Lindahl T. (2001) Human DNA repair genes. Science.; 291: 1284-9. 